\title{
Optimalisasi Potensi Alam Sebagai Scientific Problem Orientation Untuk Mewujudkan Pembelajaran IPA Yang Bermakna
}

\author{
Optimalization of the Nature Potency as Scientific Problem Orientation \\ for Meaningful Learning
}

\author{
Asri Widowati*, Widodo Setyo W, dan Putri Anjarsari \\ *Jurusan Pendidikan IPA, email: asri_widowati@uny.ac.id.
}

\begin{abstract}
Abstrak
Kegiatan PPM ini ditujukan untuk: (1) Membekali keterampilan scientific problem orientation (merumuskan persoalan dan merancang pemecahannya) berdasarkan gejala alam; (2) Mengemas pemanfaaatan potensi alam dalam pembelajaran IPA; (3) Menghasilkan produk berupa hasil pemetaan potensi alam untuk pembelajaran IPA, hasil rancangan kegiatan pemecahan masalah secara ilmiah berdasarkan gejala alam, dan Rencana Pelaksanaan Pembelajaran IPA. Sasaran kegiatan adalah guruguru IPA SMP di Kabupaten Magelang. Kegiatan disajikan dengan metode ceramah, demonstrasi, eksplorasi, workshop. Instrumen evaluasi berupa lembar penilaian produk peta sumber belajar dan produk rancangan kegiatan ilmiah serta Rencana Pelaksanaan Pembelajaran (RPP) IPA. Kegiatan PPM Optimalisasi Potensi Alam sebagai Scientific Problem Orientation dilaksanakan oleh tim pengabdi pada hari Sabtu dan Minggu di SMP N Mungkid. Peserta yang hadir sebanyak dua puluh enam orang guru anggota MGMP IPA SMP Kabupaten Magelang. Hasil pelatihan berupa produk hasil peta sumber belajar dengan memanfaatkan potensi alam, rancangan kegiatan ilmiah, dan RPP IPA. Hasil penilaian terhadap produk peta sumber belajar dengan memanfaatkan potensi alam menunjukkan bahwa sebagian besar peserta $(>75 \%)$ sudah mampu memanfaatkan alam sebagai persoalan pembelajaran, dan juga sudah mampu melakukan scientific problem orientation (merumuskan persoalan dari alam beserta fenomenanya da merancang kegiatan ilmiah). Sebagian besar kelompok sudah mampu menyusun RPP IPA berpendekatan inkuiri.
\end{abstract}

Kata kunci: IPA, alam, scientific problem orientation.

\begin{abstract}
This activity was aimed: (1) to give the scientific problem orientation skills of teachers in teaching science based on the nature phenomena, (2) to package the using of nature potency in science learning, and (3)to produce the nature potency map, scientific activity design, and lesson plan. The target activities are junior teachers in Magelang regency. Event presented by the lecture method, demonstration, exploration and discussion. The evaluation instruments are the map learning resource's, the scientific activity design's, and lesson plan's assessment sheet. This activities "Optimalization of Nature Potency as Scientific Problem Orientation for Meaningful Learning" carried out by a team of devotees on Saturday and Monday, at SMP N 1 Mungkid. Participants who attended as many as 26 junior high school science teacher MGMPs members of Magelang Regency. The results in the form of product are learning resource map with using nature potency, scientific activity design, and lesson plan of science learning. The assessment results of the learning resource map shows that most of the participants have been able to use nature paotency in the science learning and they can do scientific problem orientation too. Most of the group can make lesson plan with inquiry approach.
\end{abstract}

Key words: nature, scientific problem orientation 


\section{PENDAHULUAN}

Pembelajaran IPA membantu siswa untuk memahami aspek-aspek yang ada di sekitar mereka, baik lingkungan alam maupun penerapan IPA. Pembelajaran IPA SMP untuk mulai membentuk konsepkonsep melalui kegiatan eksplorasi ataupun eksperimen. Namun masih ada sebagian guru masih menganggap bahwa IPA merupakan tidak lebih dari presentasi dengan papan tulis atau white board, berkoar-koar dengan jargon ilmiah, mengkopi konsep-konsep dari buku IPA. Sebagian yang lain sudah mengembangkan hands-on dan metode interaktif, mengajukan pertanyaan untuk diselidiki siswa. Maka pertanyaan yang muncul, saat ini kita sebagai guru IPA mengajarkan IPA pada pihak yang mana?

Berdasarkan hasil survey di Kabupaten Magelang terdapat berbagai potensi alam yang beraneka ragam, halaman beberapa SMP di Kabupaten Magelang luas dan memiliki berbagai potensi alam di halaman sekolah berupa kolam, kebun, taman, dsb. Dan di bagian luar pagar sekolah juga terdapat kandang, sawah, rawa, dsb. Potensi alam tersebut sangatlah berpotensi untuk dijadikan objek pembelajaran IPA. Berdasarkan wawancara beberapa orang guru saat kegiatan PPM tahun 2015 diperoleh informasi bahwa (1) sebagian besar $(>75 \%)$ guru mengalami kesulitan memanfaatkan potensi alam di sekitar sekolah sebagai media belajar IPA, dengan alasan belum tahu bagaimana cara memanfaatkannya, belum paham apa yang dapat dipersoalkan pada objek tersebut; (2) sebagian besar $(>75 \%)$ guru masih mengalami kesulitan dalam mengorientasikan siswa dengan persoalan yang bersumber dari gejala alam dan sekaligus merancang pembelajaran pemecahan masalah berdasarkan gejala yang muncul dari objek yang ada di alam (dalam hal ini disebut scientific problem orientation); (3) sebagian kecil $(<50 \%)$ guru sudah berusaha mencoba menggunakan potensi alam di sekitar sekolah, namun dirasa hasil belajar yang diperoleh tidak sesuai dengan harapan yang diinginkan. Adanya kesulitan tersebut, khususnya dalam hal scientific problem orientation yang bersumber dari gejala alam menyebabkan sebagain besar guru membelajarkan IPA secara text book. Hal ini tentunya tidak sesuai dengan hakikat pembelajaran IPA.

Berdasarkan fakta-fakta tersebut maka dapat disimpulkan bahwa guru mengalami kesulitan dalam memanfaatkan potensi alam untuk membelajarkan IPA kepada siswa. Tentunya masalah tersebut penting untuk diatasi, mengingat objek IPA berupa alam, maka sudah sepatutnya guru harus berusaha menginteraksikan siswa ke alam, bukan hanya text book. Hal ini supaya IPA dipelajari bukan sebagai teori belaka. Ratno Harsanto (2005) menyatakan bahwa masih banyak pembelajaran yang berorientasi pada upaya mengembangkan dan menguji daya ingat siswa sehingga kemampuan berpikir siswa direduksi dan sekedar dipahami sebagai kemampuan mengingat saja. Selain itu, hal tersebut juga berakibat siswa terhambat dan tidak berdaya menghadapi masalah-masalah yang menuntut pemikiran dan pemecahan masalah secara kreatif.

Belajar IPA pada hakikatnya untuk menginteraksikan siswa dengan objek, maka dituntut juga kontekstualitasnya sehingga tidak terjadi gap antara IPA dengan kehidupan sehari-hari. Hal ini senada dengan Tedjo Susanto (2006:1) yang menekankan bahwa dasar-dasar IPA dapat dijumpai pada macam-macam kejadian sehari-hari. Namun agar dasar-dasar tersebut dapat dipahami siswa perlu diadakan pengajaran yang seksama. Pengajaran IPA yang tepat selain akan memperdalam pengertian siswa-siswa yang tepat selain akan memperdalam pengertian siswa akan peristiwa alamiah, juga akan membuat mereka semakin kritis, logis, dan sistematis dalam cara berpikir, dan hal ini sangat besar pengaruhnya pada sikap dan tindakan mereka. Pengertian yang diperoleh para siswa dari pembelajaran akan membuat 
siswa dapat menginsafi dan menghargai pentingnya alam sekitar bagi pendidikan.

Alam sekitar menyediakan begitu banyak gejala benda dan peristiwa untuk pembelajaran IPA. Potensi semacam itu secara riil belum termanfaatkan dengan baik. Padahal alam sekitar dapat dimanfaatkan untuk media belajar yang murah, menarik, dan mampu memberikan pengalaman konkrit bagi siswa. Pemanfaatan lingkungan untuk pembelajaran IPA tergantung pada kemauan, kemampuan, dan kreatifitas guru.

$$
\text { Pembelajaran IPA yang }
$$

menginteraksikan siswa dengan alam akan mewujudkan pembelajaran IPA yang otentik dan bermakna. Pembelajarn bermakna dapat menumbuhkembangkan ketrampilan ilmiah dan kemampuan untuk berpikir kreatif sehingga dapat menyelesaikan berbagai masalah yang ada. Siswa perlu difasilitasi belajarnya untuk melatih ketrampilan ilmiah dan kemampuan berpikir kreatifnya dengan mengangkat persolaan pembelajaran dan membelajarkan siswa bagaimana cara pemecahannya. Tentunya guru perlu memiliki keterampilan dalam menyelenggarakan pembelajaran otentik. Selain itu juga perlu memiliki keterampilan untuk membuat media ajar yang dapat mendukung penyelenggarakan pembelajaran otentik.

Agar pemanfaatan alam sekitar yang tergelar dapat secara efektif mengarahkan pada pencapaian konsep yang dipelajari, guru harus mampu mengorganisasikannya dan memandu kegiatan siswa. Aktivitas guru memanfaatkan alam sekitar sebagai sumber belajar IPA sebagai aspek perilaku, akan dipengaruhi oleh persepsi dan sikapnya terhadap tugas-tugas profesinya, juga persepsi terhadap potensi objek alam sekitar sebagai pendukung kegiatan pembelajaran. Dengan demikian guru akan menentukan persepsi serta sikapnya terhadap potensi objek alam sekitar. Selanjutnya persepsi atau sikap yang dimiliki akan menentukan perilaku guru dalam melaksanakan tugastugas profesi, termasuk di antaranya perilaku memanfaatkan objek alam sekitar pada pembelajaran IPA yang diampunya. Tentunya permasalahan tersebut harus segera diatasi agar tidak berkelanjutan. Oleh karena itu, perlu dilakukan pelatihan optimalisasi alam sebagai scientific problem orientation untuk mewujudkan pembelajaran IPA yang bermakna.

Keterampilan guru dalam menangkap gejala dari objek berupa alam dan menjadikannya sebagai persoalan pembelajaran dan merancang pembelajaran otentik untuk memecahkan persoalan tersebut masih kurang. Padahal belajar IPA adalah belajar alam, bukan belajar teori-teori belaka dari buku. Berdasarkan uraian di atas maka masalah yang dapat dirumuskan adalah bagaimana cara mengasah keterampilan guru dalam mengoptimalisasi alam sebagai objek persoalan pembelajaran IPA untuk mendukung pembelajaran otentik? Dalam kegiatan ini difookuskan pada keterampilan guru dalam merumuskan persoalan berdasarkan gejala alam, merancang kegiatan ilmiah untuk memecahkan persoalan tersebut, dan merancang pembelajaran yang mengangkat persoalan tersebut dalam pembelajaran IPA SMP.

\section{SOLUSI/TEKNOLOGI}

Pemecahan masalah untuk menjawab masalah adalah dengan menyelenggarakan workshop secara intensif yang mencakup bagaimana cara memetakan potensi alam di sekitar sekolah, merancang pemecahan persoalan bersumber gejala alam dan mengemas pemanfaatan potensi alam dalam pembelajaran IPA, berupa RPP IPA.

Adapun metode yang digunakan dalam kegiatan ini sebagai berikut.

1. Ceramah digunakan untuk memberikan informasi tentang: (1) Pembelajaran IPA Bersumber Potensi Alam; (2) Investigasi dalam Pembelajaran IPA.

2. Demonstrasi digunakan untuk memberikan contoh penyelidikan dengan objek dan persoalan yang bersumber dari alam sekitar sekolah. 
3. Eksplorasi dan diskusi digunakan untuk memberikan kesempatan kepada guru untuk melakukan latihan pemetaan potensi alam di sekitar.

4. Workshop digunakan untuk melatih guru dalam merancang kegiatan penyelidikan bagi siswa dan mengemaskan dalam pembelajaran IPA dalam bentuk RPP.

5. Peerteaching digunakan untuk melatih guru dalam membelajarkan siswa dengan persoalan dan kegiatan yang menginteraksikan siswa dengan alam, baik indoor maupun outdoor.

Evaluasi kegiatan ini dilakukan dengan dengan menggunakan lembar penilaian produk yang meliputi: peta potensi alam, rancangan kegiatan ilmiah yang bersumber gejala alam, dan RPP.

Tabel 1. Metode Kegiatan PPM

\begin{tabular}{|c|c|c|c|c|}
\hline $\begin{array}{l}\text { Hari ke- } \\
\text { ke- }\end{array}$ & Materi & Media dan Alat & Metode & $\begin{array}{r}\text { Waktu } \\
\text { (menit) }\end{array}$ \\
\hline \multirow[t]{2}{*}{1} & $\begin{array}{l}\text { Materi: (1) Pembelajaran IPA } \\
\text { bersumber potensi alam; } \\
\text { (2)Investigasi dalam } \\
\text { Pembelajaran IPA dan } \\
\text { pengelolaannya }\end{array}$ & $\begin{array}{l}\text { Laptop,LCD, Slide } \\
\text { Ppt materi }\end{array}$ & Ceramah & 90 \\
\hline & Contoh proses penyelidikan & $\begin{array}{l}\text { Alat dan bahan } \\
\text { untuk demonstrasi }\end{array}$ & Demonstrasi & 60 \\
\hline \multirow[t]{2}{*}{2} & $\begin{array}{l}\text { Menginventarisasi: persoalan } \\
\text { IPA yang dapat diinvestigasi } \\
\text { yang sesuai dengan } \\
\text { Kebutuhan belajar, Berlatih } \\
\text { berinkuiri di alam }\end{array}$ & $\begin{array}{l}\text { Alam, Kertas, Alat } \\
\text { Tulis, Lembar } \\
\text { Kegiatan Guru }\end{array}$ & $\begin{array}{c}\text { Eksplorasi, } \\
\text { Diskusi }\end{array}$ & 90 \\
\hline & $\begin{array}{l}\text { Rancangan kegiatan } \\
\text { penyelidikan untuk Kegiatan } \\
\text { Siswa dan pembelajarannya }\end{array}$ & $\begin{array}{l}\text { Hasil peta potensi } \\
\text { alam, kurikulum } \\
\text { IPA, alat dan bahan }\end{array}$ & $\begin{array}{c}\text { workshop } \\
\text { rancangan } \\
\text { Lembar } \\
\text { Kegiatan } \\
\text { Siswa dan } \\
\text { RPP }\end{array}$ & 60 \\
\hline 3 & $\begin{array}{l}\text { Implementasi Scientific } \\
\text { Problem orientation }\end{array}$ & & Peerteaching & 150 \\
\hline
\end{tabular}

Selain itu, digunakan pula lembar observasi workshop dan peerteaching untuk mengukur keaktifan peserta.

\section{HASIL DAN DISKUSI}

Peserta yang hadir dalam kegiatan PPM "Pengembangan Kreativitas Guru dalam Pembelajaran IPA dengan Berinkuiri" sebanyak dua puluh enam (26) orang. Hal tersebut melebihi target kuantitatif 15 orang peserta). Hal ini dikarenakan alokasi waktu pelaksanaan sudah berdasarkan kesepakatan dengan pengurus MGMP IPA SMP dan undangan kegiatan dapat disebarkan tepat waktu serta tepat sasaran.

Inti kegiatan PPM berupa Proses pelatihan guru dalam menganalisis kurikulum yang dapat berpotensi dibelajarkan dengan menggunakan potensi alam ataupun sebaliknya. Tahap pertama analisis kurikulum secara mandiri menggunakan kurikulum yang berlaku di sekolah masing-masing. Adapun proses analisis kurikulum yang dihasilkan sebagai hasil pemetaan sumber belajar dengan pemanfaatan potensi alam.sebanyak 26 buah $(\mathrm{N}=26)$, dengan lebih dari $75 \%$ mencapai 
kualitas Baik dan Sangat baik. Rincian sebagaimana Gambar 1.

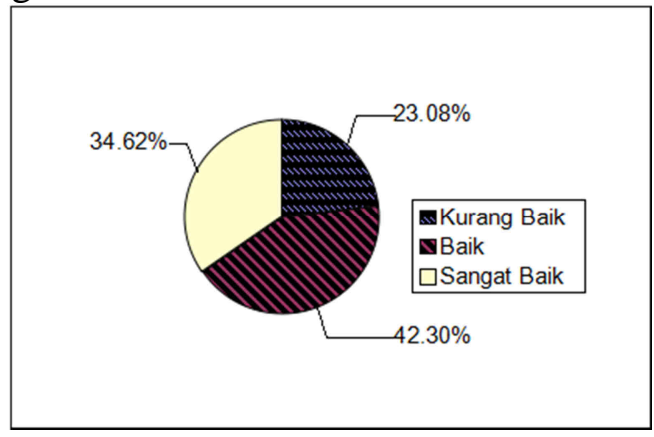

Gambar 1. Pie Chart Hasil Penialaian

Analisis Sumber Belajar dari Alam

$\begin{array}{lll}\text { Sangat baik : } & \text { jika analisis kompetensi } \\ & \text { benar, pemilihan } \\ & \text { kegiatan pembelajaran, } \\ & \text { bahan ajar dan potensi } \\ & \text { alam tepat } \\ & : \text { jika salah satu komponen } \\ & \text { tidak terpenuhi } \\ \text { Baik } & : \text { jika lebih dari satu } \\ \text { Kurang } & \text { komponen } \\ \text { Baik } & \text { terpenuhi }\end{array}$

Keterangan:

Pada pelatihan eksplorasi tahap kedua, kreativitas peserta dalam mengembangkan langkah penemuan konsep sudah muncul, yakni dengan adanya perumusan masalah pembelajaran. Pada awalnya guru merasa kesulitan, terutama dalam hal menyusun pertanyaan berdasarkan hasil pengamatan dan sistematika langkah kegiatan yang dapat memfasilitasi siswa berinkuiri. Hasil praktik scientific problem orientation berupa rancangan kegiatan lembar kegiatan ilmiah sebanyak 26 buah, sebagaimana Gambar 2.

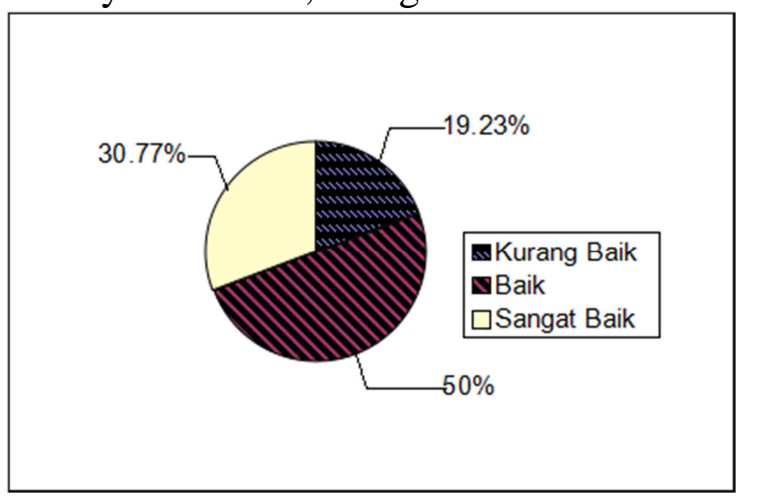

Gambar 2. Pie Chart Hasil Penilaian Rancangan Kegiatan Ilmiah
Keterangan :

Sangat baik : jika persoalan berupa pertanyaan investigatif , tujuan kegiatan tepat (bukan verifikatif), alat dan bahan lengkap, langkah kegiatan pembelajaran sistematis, pertanyaan diskusi dalam rancangan kegiatan sesuai dengan kegiatan yang dilakukan.

Baik : jika salah satu komponen tidak terpenuhi

Kurang : jika lebih dari satu Baik komponen tidak terpenuhi

Hasil berupa RPP sebanyak 6 (dari 6 kelompok) dengan 4 buah sudah berkualitas baik dan 2 masih kurang. Adapun catatan dari produk RPP yang dihasilkan adalah: format RPP sudah lengkap dan sistematis, hanya saja ada 2 RPP dengan tujuan pembelajaran yang kurang operasional dan langkah pembelajarannya kurang tepat karena kegiatan ilmiah disetting sebagai pembuktian.

Berdasarkan hasil-hasil tersebut tampak bahwa sebagian besar peserta sudah dapat melakukan pemetaan potensi alam untuk pembelajaran IPA dan mampu melakukan scientific problem orientation (merumuskan persoalan dan rancangan kegiatan investigasi) bersumber pada gejala alam, dan mengemasnya dalam pembelajaran IPA.

Sebagai tindak lanjut agar dapat meminimalkan hambatan saat implementasi inkuiri secara real di sekolah, maka perlu diberikan pemahaman tentang teknik bertanya. Hal tersebut dikarenakan pertanyaan merupakan langkah awal bagi guru agar dapat memfasilitasi siswa dalam berinkuiri. Secara umum, dapat dikatakan kegiatan ini berhasil karena semua peserta sudah dapat berlatih berinkuiri dan membuat langkah pembelajaran dengan mengimplementasikan inkuiri. Hal tersebut dikarenakan adanya 
faktor-faktor yang mendukung dan kunci keberhasilan kegiatan. Adapun faktor pendukung kegiatan ini, antara lain: (1) Sumber belajar berupa alam di sekitar sekolah peserta sangat mendukung kegiatan PPM; (2) Narasumber pernah mendapatkan pelatihan potensi alam untuk membelajarkan IPA kepada siswa di pendidikan dasar; (3) Semangat dan antusiasme peserta untuk meningkatkan kemampuan mengajar dengan inkuiri; (4) Kesadaran guru tinggi terkait perubahan paradigma bahwa pembelajaran dapat lebih mengaktifkan siswa (studentcentered). Adapun faktor-faktor kunci keberhasilan kegiatan ini, yakni: (1) Materi pelatihan sesuai dengan yang dijadwalkan; (2) Guru-guru (peserta) antusias untuk mengembangkan langkah pembelajaran dengan inkuiri beserta alat pendukungnya dalam pembelajaran.

Berdasarkan hasil evaluasi kegiatan, diperoleh informasi bahwa $100 \%$ peserta menyatakan bahwa kegiatan ini bermanfaat bagi pembelajaran di sekolah dan sebagian besar $(75 \%)$ merasa kegiatan pelatihan ini belum cukup karena mereka menginginkan adanya kesinambungan dalam kegiatan PPM yang dilaksanakan oleh tim pengabdi FMIPA.

\section{KESIMPULAN}

Adapun hasil simpulan kegiatan

PPM sebagai berikut.

1. Sebagian besar peserta sudah dapat melakukan pemetaan sumber belajar dengan memanfaatkan potensi alam

2. Sebagian besar peserta sudah dapat melakukan scientific problem orientation, yang ditunjukkan dengan hasil rancangan kegiatan ilmiah yang berkategori baik sudah lebih dari $75 \%$

\section{UCAPAN TERIMA KASIH}

Kami mengucapkan terimakasih kepada pihak Dekan beserta jajarannya atas ijin dan dukungannya terhadap pelaksanaan kegiatan ini, Pengurus dan anggota MGMP IPA Kabupaten Magelang atas partisipasi aktif dalam kegiatan PPM ini dan kerja samanya.

\section{PUSTAKA}

Chamber, D. 1991. Instructional design for meaningful learning. Instructional Science. Netherlands: Kluwer Academic Pub, Dordrecht .

Drake. 2012. A Critical Analysis of Active Learning and an Alternative Pedagogical Framework for Introductory Information Systems Courses. Journal of Information Technology Education: Innovations in Practice Volume 11.

Djohar. 1987. Peningkatan Prooses BelajarMengajar Sains Melalui Pemanfaatan Sumber Belajar. Jurnal Kependidikan no. 2 vol. 17. Yogyakarta : IKIP Yogyakarta.

NSTA. 2003. Standards for Science Teacher Preparation. Revised edition. Washington, DC: National Academy Press.

National Research Council. (1996). National science education standards. Washington: National Academy Press.

Reiter S. 2015. Meaningful Learning in Special Education Teaching and Learning Based on the Cycle of Internalized Learning: A Review. Open Journal of Social Sciences, 2015, 3, 103-111, diunduh dari http://www.scirp.org/journal/jss http://dx.doi.org/10.4236/jss.2015.39 016.

Tedjo Susanto. 2006. Pendidikan Sains. Yogyakarta: FMIPA, UNY. 